\title{
Housing for the aging population
}

\author{
Halime Demirkan
}

Received: 16 August 2006 / Accepted: 22 January 2007 / Published online: 15 February 2007

(C) EGREPA 2007

\begin{abstract}
Based on the concept of 'aging in place,' design of houses in the past years are explored. Design features in the built environment become barriers for aging people with functional limitations. Initially, houses were designed according to the required needs of the user with the physical limitations. Later, adaptable house design was introduced that allows the house to meet the specific needs of the user, while maintaining the appearance of the house until more obvious accessibility features are needed. Today, 'design for all' is recognised as a tool for ensuring physical accessibility for aging people. The holistic perspective embedded in the universal design theory should be systematically and consistently developed during the design process.
\end{abstract}

Keywords Aging · Functional limitations .

Physical accessibility $\cdot$ Universal design

\section{Introduction}

The increase in life expectancy, the resulting growth of the elderly population and the preference to age in familiar environments are the driving forces for architects to consider aging population in the design process. It is estimated that Europe will have 173 million people aged 65 and above by 2050 [34]. According to UN projections, almost one third of the population (32.5\%) will be aged 65 or older in 2050 [68]. Aging is most serious in Southern

\section{H. Demirkan $(\bowtie)$}

Department of Interior Architecture and Environmental Design, Faculty of Art, Design and Architecture, Bilkent University, Ankara 06800, Turkey

e-mail: demirkan@bilkent.edu.tr
Europe. In Northern Europe, by contrast, 'only 25\%' of the population will be aged or older in 2050 . These estimates show that there will be a demand of housing for a number of aging people, and the supply will not be sufficient. If a house is inadequate for the needs of people living in it, it never becomes a home. For the aging population, a house must be fully accessible to become a home.

Treffers [65] stated that "designing places and spaces for all means designing society, including aging people" (p. 3). Older people become disabled as they experience a decline in hearing and sight as well as their mobility. Physical design issues become barriers for aging people. There are some studies that examined relationship between life in the home and the well-being of the elderly [15-20, 26, 56, 57]. Because there is a limitation in outside physical activities, aging people focus more on the activities in their residences. Their homes become the only places that they can maintain social bonds with individuals and their community. Researches have shown that psychological well-being is one of the most intrinsic aspects of successful aging $[10,41,58]$. Housing must fulfil the needs for the daily activities of the elderly and give the feeling of satisfaction, security, comfort and independence [16].

Previous studies for the elderly housing were mostly focused on senior housing, sheltered housing, nursing houses and community dwellings rather than private housing. The global aging phenomenon highlights the disparity between traditional housing and the actual standard of housing required to enable people to live in their homes as their needs change. Studies have identified various factors having impacts on the psychological wellbeing of the elderly including housing and neighbourhood environments. Environmental psychologists were showing positive links between perceived well-being in the home and the quality of the residential environment [11, 40, 49, 
69]. It is reported that elderly residents with diminished abilities, if they are familiar with the surroundings, can carry out daily life activities nearly successfully. On the contrary, these activities can be very hard to carry out, even by less disabled elderly, when they are not familiar with the surroundings $[40,49]$.

Although research from other disciplines shows effects of the built environment on human happiness and welfare, the design professional is required to reach beyond the known application of design knowledge and previously conceived solutions [53]. An understanding of the requirements of aging people must be considered from the preliminary phase of design. It is critical that the needs of the elderly be addressed in the initial phase; not only does this avoid costly design changes later, but more importantly, addressing these needs as an afterthought depicts segregation.

\section{Accessible housing design}

Many studies were conducted in attempts to design better houses and interiors for the elderly. However, the opinion of the elderly themselves related to the design itself is rarely considered. Women's Design Service was set up in London in the 1980s to provide advice and information on the requirements of elderly women [9]. This was a collaboration medium for architects and users to improve standards and choices in housing design. The findings of these collaboration sessions were published as a publication titled 'Designing Housing for Older People' [8]. Then, many designers started to participate or collaborate with the elderly people during the design process of houses [16-19] or house renovation [57].

Accessible generally means that the dwelling meets prescribed requirements for accessible housing [21, 29]. Accessible features in dwellings include items such as wide doors, sufficient clear space for wheelchairs, loop-type handles on hardware, grab bars in the bathroom and knee spaces under the sink. These features are permanently fixed in place and very apparent [29]. There is a broad body of written documents that refer to the accessibility of elderly and disabled people. These include the standards [7, 21], references [32] and norms that guide the design process. These European documents were similar to American National Standards (ANSI A117.1) [2] and Fair Housing Act Design Manual Guidelines [30] in the USA. In the past years, there has been a development towards considering groups with special needs in the design process within the context of given information in the standards and reference documents. This was mostly achieved by a specialised solution in addition to the regular one [22]. Comparison of housing policies for the aged persons in different countries can be found in Brink [6]. Thus, the provided solutions in the design process should include all users in a holistic perspective.

In December 1993, the United Nations [67] invited its member states to find solutions to the increasing number of elderly people and those with functional limitations amongst populations in many regions of the world. 'United Nations Standard Rules on the Equalization of Opportunities for Persons with Disabilities' specified 22 concise rules stipulating how designers in the member states could prepare designs for integration and provide equal opportunities for people with functional limitations. As a result, standard organisations started to develop standards and issue guidelines addressing the people with physical limitations.

In many design guides, the requirements for people with changing needs are stated with special emphasis given to the needs of people who are extremely mobility-impaired like wheelchair users [57]. The needs of aging people are mentioned in a general context or within a few sentences. Therefore, many of the recommendations are not specifically useful for all people with minor limitations. For a designer, it is hard to make a decision for an actual solution. Sagdic and Demirkan [57] proposed a design decision support system to support designers during design process. Further studies were conducted for integration of reasoning systems in architectural modelling activities [23-25]. Findings of Sagdic and Demirkan's [57] study on habitual activities and daily living of the Turkish elderly supported Imamoglu and Imamoglu's [35] study on housing of the Turkish elderly. They also found that there were gender differences in preferences while using interiors that were not considered in the standards.

\section{Adaptable housing design}

Research on housing highlights a growing discordance between the users' requirements and housing standards even in western societies [36, 46, 52, 64]. The major cause of this discordance is the neglect of the individual differences in dwelling habits by the designers and planners [31]. The researches conducted in this field are mostly restricted to the evaluation of housing satisfaction as opposed to residential satisfaction [54], although they are closely interrelated [37]. Although, a few are interested in the analysis of house plans and found out that interior spatial layouts had changed significantly over the years [33].

Many non-disabled people prefer not to live in accessible dwellings because of its clinical outlooks, and the clearances for the able bodies were considered as lost spaces such as clearance under the counter instead of base cabinet storage space in the kitchen. Many people did not use the houses with accessible features. To overcome these 
problems, adaptable features were introduced. "Adaptable features are either adjustable or capable of being easily and immediately added or removed to 'adapt' the unit to individual needs or preferences" ([29], p. 2).

For some, adaptation may be as simple as adding grab bars and a seat to the bathtub. For wheelchair users, it may require ramping entrances, widening doorways, lowering counter surfaces, lever-type handle to doors and drawers and modifying storage areas. Individuals with sensory disabilities may require visual adaptations for such items as the telephone ringer, the doorbell and smoke alarms. People who are visually impaired may require tactile marking of changes in floor level and stair edges and Braille markings on appliances and controls [22].

With adaptation, in addition, some terms like 'enabling environments' and 'home modifications' were started to be popular. Developing enabling environments through removal of barriers includes the utilisation of architectural and interior design modifications and building technologies $[42,50,60]$. The level of disability of the elderly plays a role in the extent of modifications. Pynoos et al. [51] recommended that data on individual differences, acceptance and priorities were valuable for the implementation of home modifications. These data could help improve design of assistive technology, consumer products and building technology.

Morini and Pomposini [47] analysed a number of countries in Europe such as Italy, The Netherlands, Great Britain and France for their tendencies to the housing demand from the aging population perspective in 1996. They stated that accessibility and adaptability were specified in the Ministerial Decree of 1989 [14] that linked these terms to the law on the architectural barriers free of the same year in Italy. In The Netherlands, the Senior Citizen organisation with the Steering Committee for Experiments in Housing constituted The Senior Citizen Label which is a consumer quality certificate for new housing [47] that states four types of requirements, namely, safety, ease of use, accessibility and adaptability. Morini and Pomposini [47] also reported that in 1996, UK had not extended building regulations concerning access and facilities for disabled to domestic buildings yet. In France, they [47] reported that accessibility was an already accepted concept and defined in the building codes for having the elderly in their familiar environments. They also added that in 1995, Ewart [28] has proposed adaptable housing as better and safer for everyone, although it is more cost effective in the long term.

Lansley [39] thought that in UK, national building research did not have common initiatives focused towards achieving an inclusive society with the other developed countries. Although there were building regulations, since 1995, "little emphasis was given to the needs of older people and disabled people" ([39], p. 63). In 1995, a report about the implications of the changing age structure of the population was published [63]. The term EQUAL (Extend Quality Life) was the focus on the needs of older people (http://equal.ac.uk). EQUAL is a national research initiative designed to encourage university-based academics and researchers to become involved with quality-of-life research for the benefit of older people and disabled people and, more generally, to meet the challenges of the aging population in the UK. In 1998, the Engineering and Physical Sciences Research Council launched a special initiative to enable research engineers, designers and physical scientists and social, medical and health scientists to collaborate and to work directly with older people, disabled people and their representatives on issues that were of fundamental importance to improving the quality of life. The theme 'design for all' was added to EQUAL in 1998 [39]. The concepts of barrier-free and lifetime homes are considered in the UK community.

\section{Design for all (universal design)}

Although codes and standards for the benefit of people with mobility limitations specify accessible or adaptable design requirements, the universal design approach targets all people of all ages. Universal design is defined in the USA as "an approach to creating environments and products that are usable by all people to the greatest extent possible" ([45], p.156). There are seven principles of the universal design as seen in Table 1. Story et al. [61] stated that its root is deep and strong throughout the twentieth century because of the demographic, legislative, economic and social changes among older adults and people with disabilities. A universal design feature is any component of a house that can be used by everyone regardless of ability or disability. The definition also started many discussions on the issue on what is a design that is 'usable by all people.' Consequently, many international standards on usability are published to support this issue [5].

Although the universal design is not a recently coined term, it has not called attention to architects and engineers over the past years in Europe. The term 'design for all' is used instead of the universal design in Europe. The European Institute for Design and Disability played a decisive role and chose the term 'design for all' [27] in 2005. Trost [66] stated the difference between these two terms, as the universal design suggests a comprehensive philosophy, whereas the 'design for all' relates to practical applications. This comprehensive philosophy is explained as the holistic approach for all users that do not include disabled people as a specialised group. 
Table 1 The principles of the universal design [12]

\begin{tabular}{|c|c|}
\hline Principles & Description \\
\hline 1. Equitable use & The design is useful and marketable to people with diverse abilities \\
\hline 2. Flexibility in use & The design accommodates a wide range of individual preferences and abilities \\
\hline 3. Simple and intuitive use & $\begin{array}{l}\text { Use of the design is easy to understand, regardless of the user's experience, knowledge, } \\
\text { language skills or current concentration level }\end{array}$ \\
\hline 4. Perceptible information & $\begin{array}{l}\text { The design communicates necessary information effectively to the user, regardless of ambient } \\
\text { conditions or the user's sensory abilities }\end{array}$ \\
\hline 5. Tolerance for error & The design minimises hazards and the adverse consequences of accidental or unintended actions \\
\hline 6. Low physical effort & The design can be used efficiently and comfortably and with a minimum of fatigue \\
\hline 7. Size and space for approach and use & $\begin{array}{l}\text { Appropriate size and space is provided for approach, reach, manipulation and use, regardless } \\
\text { of the user's body size, posture, or mobility }\end{array}$ \\
\hline
\end{tabular}

In 1997, Aslaksen et al. [3] from The Norwegian State Council on Disability claimed that although there is an improvement in the usability of both buildings and outdoor areas in the last 20-30 years, there are still poor design solutions because of the lack of knowledge and competence of architects and planners. Besides, they pointed that more effort should be given to understand various needs and wishes of the population for better solutions. Although they recommended the universal design for having better design solutions, they pointed out that there was a gap between the best possible solution for the individual and the actual one. They added that consideration must be given to a whole series of conditions such as social considerations as economy, aesthetic design, sustainable development and cultural qualities in the process of planning and development. Therefore, the principles of the universal design should be seen as a quality assurance process in the whole architectural design process. In applying the principles, there may be conflicts between issues, and the designer should decide upon the priorities of these issues. They concluded that the imperfection in theory and methodology should not be interpreted as an obstacle in implementing the universal design in practice.

For Norwegian architects and planners, an interactive medium was presented for integrating accessibility and the universal design into architecture [13]. It provides a communication media through sketches and text as well as pictures of built examples and checklists. According to Christopherson [13], the dominant detached, single-family housing in Norway is capable of accommodating universal design principles.

Designers are now aware of the changing role of designers and the function of universal design education. On the 15th of February, 2000, the Council of Europe adopted a resolution to introduce the principles of the universal design to school programs for professions involved in the built environment [55]. Despite this European legislation in favour of design for all, the architects and designers were not educated to apply it in the design process. Therefore, the AAOutlis [38] project co-funded by the European Union LEONARDO Program started to build innovative teaching tools for the universal design for architects and architectural students in Europe. With Belgium being the coordinator, Denmark, France and Poland were the other partners of the project.

Research related to the universal design flourished more in the product field [4, 19, 20, 59, 62] than architecture [44]. The architecture literature sources mostly provide the requirements of elderly users for a safe and functional environment [16, 18, 57]. In addition, some sources have developed a list of characteristic features of universal houses as checklists [43]. Recently, a building survey [48] is developed as a tool for evaluating the existing buildings from a human-centred perspective. Examining the checklists or building surveys, it is found that there are many universal design principles to cover, as well as one principle may comprise the others. Besides, for a novice designer, it is hard to rank these principles. The holistic perspective embedded in the universal design theory should be systematically and consistently developed during the design process. A survey should guide the design process and provide criteria for new usable environments. A building survey may encourage alternative universal design solutions rather than one accessible solution.

\section{Future research}

Accessibility to the built environment was recognised internationally in 1993 by the United Nations Standard Rules on the Equalization of Opportunities for Persons with Disabilities [67]. Almost every country in the world signed the standard rules, and rule 5 defined all the issues of accessibility including the accessibility to the built environment. For many years, standard organisations have been developing standards and issuing guidelines addressing the needs of people with disabilities in the built environment. However, these developments were segregating diversified 
groups instead of dealing with the whole population. The Expert Group of the European Commission on Full Accessibility published a report entitled '2010, a Europe Accessible to All' [1]. This report indicated the lack of awareness of designers as one of the obstacles in achieving accessibility to the built environment. In this report, "accessibility means providing buildings and places which are designed and managed to be safe, healthy, convenient and enjoyable to use by all members of society. It implies that buildings should be accessible, that they should be really usable from ground floor to the top, and that adequate means of autonomous exit should be provided" ([1], p.6). Accessibility for all is therefore no longer limited to a minority with special needs. Designers, architects, urban designers and others should be designing buildings and objects to accommodate a diversity of people concerned by accessibility issues. Accessibility should be addressed in the wider perspective of spatial planning. An accessible environment is safer and healthier, thus avoiding accidents while allowing aging people to enter. An accessible environment is more comfortable, as it is more livable. Furthermore, it is more adaptable, as it accommodates later changes. The Expert Group of the European Commission concluded that "all legislation, standards, guidelines, etc should be designed and implemented with an aim to make the built environment accessible and usable by all those who could be expected to use it" (p. 13). In addition, it is stated that the construction works, products of information and communication technologies should be amended considering the essential requirements to include accessibility for all.

Design for all is recognised as a tool for ensuring physical accessibility for aging people, but there are many other types of accessibility, which depend on mental and physical factors. If the built environment has been designed to take into account the physical dimensions of the human being, also perceptual, motor and cognitive abilities support human activities. Therefore, the design for all is the design for human diversity, social inclusion and equality.

\section{References}

1. 2010 A Europe accessible for all. Available at: http://www.eca.lu/ upload/egafin.pdf

2. American National Standard Institute (1986) American national standard for buildings facilities providing accessibility and usability for physically handicapped people, ANSI A117.1, New York

3. Aslaksen F, Bergh S, Bringa, OR, Heggem, EK (1997) Universal design: planning and design for all. The Norwegian State Council on Disability, Oslo

4. Beecher V, Paquet V (2005) Survey instrument for universal design of consumer products. Appl Ergon 36:363-372
5. Bevan N (2001) International standards for HCI and usability. Int J Human-Comput Stud 55:533-552

6. Brink S (ed) (1998) Housing older people: an international perspective. Transaction, New Brunswick, NJ

7. BSI 1979, BS 5810 Access for the disabled to buildings. British Standard Institution, London

8. Cavanagh S (1992) Designing housing for older women. Women's Design Service, London

9. Cavanagh S (1996) The space we need: principles of housing design for older women, women with children, and parent with disabilities. In: Komut E (ed) Housing question of the others'. Chamber of Architects Turkey, Ankara, pp 67-76

10. Carp FM (1976) Housing and living environments of older people. In: Bistock RH, Shanas E (eds) Handbook of ageing and the social sciences. D. Van Nostrand, New York, pp 244271

11. Carp FM, Christensen DL (1986) Technical environmental assessment predictors of residential satisfaction. Res Aging 8:269-287

12. Center for Universal Design (1997) The principles of universal design, version 2.0. North Carolina State University, Raleigh, NC

13. Cristopherson J (1997) Varieties of barrier free design: accessible housing in five European countries - a comparative study. Norwegian Building Research Institute, Oslo

14. Decree Ministerial (1989) Decreto Ministero Lavori Publici 14 Giugno 1989 no. 236

15. Demirbilek O, Demirkan, H (1997) A collaboration model in interiors involving the elderly. In: IEA'97, International Ergonomics Association 13th Triennial Congress, vol 5, Tampere, Finland, pp 570-572

16. Demirbilek O, Demirkan H (1998) Involving the elderly in the design process. Architectural Science Review 41:157-164

17. Demirbilek O, Demirkan, H (1999) Designing with the elderly. Fourth global conference, Montreal, Quebec, Canada, p 82

18. Demirbilek O, Demirkan H (2000) Collaborating with elderly endusers in design process. In: Scrivener SAR, Ball LJ, Woodcock A (eds) Collaborative design. Springer, Berlin Heidelberg New York, pp 205-212

19. Demirbilek O, Demirkan H (2004) Universal product design involving elderly users: a participatory design model. Appl Ergon 35:361-370

20. Demirbilek O, Demirkan H, Alyanak S (2000) Designing an armchair and a door with elderly users. In: Designing for the $21 \mathrm{st}$ Century, an international conference on universal design, http:// www.adaptenv.org/21 century/proceedings5.asp\#parmchair, pp 1-3

21. Demirkan H (1991) Some criteria for designing interiors for the turkish disabled and elderly. In: 3rd Ergonomics Congress Proceedings, MPM, Ankara, pp 499-509

22. Demirkan H (1996) Adaptable house design. In Ural O, Altinbilek $\mathrm{D}$, Birgönül T (eds) Proceedings of the XXIVth IAHS World Housing Congress, how to house a nation: the challenge for the XXIst century, Middle East Technical University, Ankara, vol 1, pp 19-29

23. Demirkan H (1998) Integration of reasoning systems in architectural modelling activities. Autom Constr 7:229-236

24. Demirkan H (1999) Knowledge-based ergonomics model for the design of elderly residences. In: Proceedings of the International Conference on Computer-aided Ergonomics and Safety, Barcelona, Spain, http://www.ioc.upc.es/CAES99

25. Demirkan H (2005) Generating design activities through sketches in multi-agent systems. Autom Constr 14:699-706

26. Demirkan H, Sagdic Y (1997) Bathing facilities for all Turkish people. In: IEA'97 International Ergonomics Association 13th Triennial Congress, vol 2, Tampere, Finland, pp 346-348

27. European Institute for Design and Disability (EIDD). http://www. design-for-all.org/ 
28. Ewart K (1995) Adaptable housing from the user's viewpoint. In: CNR-ICIE-SAIEDUE 2nd international seminar on potential of innovations technologies for solving housing problems of aged people

29. Fact sheet no. 6 (1991) Housing definitions: accessible, adaptable, and universal design. HDFS.4.91, pp 1-3

30. Fair Housing Act Design Manual (1996) Fair Housing Act Design Manual: a manual to assist designers and builders in meeting the accessibility requirements of the FHA, FHADM.3.99, barrier Free Environments, 295pp Available at: http://www. huduser.org/Publications/PDF/FAIRHOUSING/fairfull.pdf

31. Giuliani MV, Rullo G, Bove G (1990) Socializing and privacy space inside homes: an empirical study. Culture Space History 3:129-138

32. Goldsmith S (1976) Designing for the disabled. RIBA, London

33. Hasell MJ, Peatros F (1990) Exploring connections between women's changing roles and house form. Environ Behav 22:3-26

34. IASA demography: population by age groups, 1950-2050 for all European regions. Available at: http://www.iiasa.ac.at/Research/ ERD/DB/data/hum/dem/dem_2.htm

35. Imamoglu EO, Imamoglu $\mathrm{V}^{-}$(1995) Housing and living environments of the Turkish elderly. J Environ Psychol 12:35-43

36. Kaplan R (1985) Nature at the doorstep: residential satisfaction and the nearby environmental. J Archit Plann Res 2:115-127

37. Kaitilla S (1993) Satisfaction with public housing in Papua New Guinea: the case of West Taraka housing scheme. Environ Behav 25:514-545

38. Kennig B, Ryhl C (2002) Teaching universal design-global examples of projects and models for teaching in universal design at schools of design and architecture. AAoutlis, ANLH, Brussels

39. Lansey P (2001) Building research and the quality-of-life. Build Res Inf 29:62-74

40. Lawton MP (1985) Elderly in context: perspectives from environmental psychology and gerontology. Environ Behav 17:501-519

41. Lawton MP, Nahemow L (1973) Ecology and the ageing process: psychology of adult development and ageing. In: Eisdorfer C, Lawton MP (eds) Psychology of adult development and ageing. American Psychological Association, Washington, pp 619-674

42. Leibrock C, Behar S (1993) Beautiful barrier-free. Van Nostrand Reinhold, New York

43. Mace RL (1998) Universal design in housing. Assist Technol 10:21-28

44. Mace RL, Bostrom JA, Harber LA, Young LC (1991) The accessible housing design file. Van Nostrand Reinhold, New York

45. Mace RL, Hardie GJ, Plaice JP (1991) Accessible environments: toward universal design. In Preiser W, Vischer J, White E (eds) Design interventions: toward a more human architecture. Van Nostrand Reinhold, New York

46. Michelson W (1980) Longitudinal study of changing aspirations by introduction the dimension of time. Soc Issues 36:135-149

47. Morini A, Pomposini R (1996) New designs for aged people housing. In: Ural $\mathrm{O}$, Altýnbilek $\mathrm{D}$, Birgönül $\mathrm{T}$ (eds) XXIVth IAHS World Housing Congress, vol 2, pp 791-800

48. Ostroff E, Weisman LK (2004) Universal design building survey: incorporating the ADA and beyond in public facilities. Available at: http://www.udeducation.org/teach/course mods/survey/index.asp

49. Parmelee PA, Lawton MP (1994) The design of special environments for the aged. In: Birren JE, Schaie KW (eds)
Handbook of the psychology of ageing. Academic, California, pp 464-488

50. Peloquin A (1994) Barrier-free residential environments. McGraw-Hill, New York

51. Pynoos J, Cohen E, David LJ, Berhardt S (1987) Home modifications: improvements that extend independence. In: Regnier V, Pynoos J (eds) Housing the aged. Elsevier, New York

52. Rapoport A (1985) Thinking about home environment: a conceptual framework. In: Altman L, Werner C (eds) Home environments. Plenum, New York, pp 255-286

53. Raschko BB (1982) Housing interiors for the disabled and elderly. Van Nostrand Reinhold, New York

54. Rent GS, Rent CS (1978) Low-income housing: factors related to residential satisfaction. Environ Behav 10:459-485

55. Resolution ResAP (2001) On the introduction of the principles of universal design into the curricula of all occupations working on the built environment, Council Of Europe, Committee of Ministers. Available at: http://cm.coe.int/ta/res/resAP/2001/2001xp1/htm

56. Sagdic Y, Demirkan H (1997) Different aspects of being elderly in residential wet spaces. In: IEA'97 International Ergonomics Association 13th Triennial Congress, vol 5, Tampere, Finland, pp 609-611

57. Sagdic Y, Demirkan H (2000) A design decision support system model for the wet space renovation of elderly people's residences. Architectural Science Review 43:125-132

58. Schwirian M (1993) Neighboring, residential satisfaction and psychological well-being in urban elders. J Commun Psychol 21:285-297

59. Steinfield E, Danford GS (1996) Automated doors: toward universal design. IDEA

60. Steinfield E, Shea S (1993) Enabling home environments: identifying barriers to independence. Technol Disabil 2(4):6979

61. Story MF, Mueller JL, Mace RL (1998) The universal design file: designing for people of all ages and abilities, revised edition. North Carolina State University, The Center for Universal Design, Raleigh

62. Story MF, Mueller JL, Montoya-Weiss M (2001) Completion of universal design performance measures. In: Proceedings of the RESNA 2001 Annual Conference, RESNA, Arlington

63. Technology Foresight Panel on Health and Life Sciences (1995) Health and life sciences. HMSO, London

64. Tognoli J (1987) Residential environments. In: Stokols D, Altman I (eds) Handbook of environmental psychology. Wiley, New York, pp 55-690

65. Treffers B (2004) Design for all: a history of discrimination by design, future cities for all. Available at: http://www.eca.lu/upload/ History $\% 20$ of $\% 20$ Dicrimination $\% 20$ by $\% 20$ Design.pdf

66. Trost G (2005) State affairs in universal design. Fujitsu Sci Tech J 41:19-25

67. United Nations (1993) Standard rules on the equalization of opportunities for persons with disabilities. A/RES/48/96. 85th plenary meeting 20 December 1993. Available at: http://www.un. org/documents/ga/res/48/a48r096.htm

68. United Nations (2001) World population prospects: the 2000 revision. United Nations, New York

69. Verderber S, Song JH (2005) Environment and aging in Japan-a review of recent research. Environ Behav 37:43-80 